\title{
Food Security in Rural Areas of Vaishali District, India: A Household Level Analysis
}

\author{
Haroon Sajjad ${ }^{* 1}$, Iffat Nasreen ${ }^{2}$
}

\begin{abstract}
:
Food security has been one of the major developmental objectives in India. Though India has sufficient food production yet the achievement did not percolate down to households. This paper reports on an investigation into the food security status in Vaishali district of Bihar. Data were gathered across 16 administrative divisions in the district and eventually 959 farmers' households were sampled using stratified random sampling techniques. This allowed computing composite food security index to assess the relative status of food security of the sampled farmers. The findings revealed that $75 \%$ of the sampled households have low food security. Within farmers' categories, most of the large farmers had high food security. Medium farmers experienced moderate food security while semimedium, small and marginal farmers were having low food security. Bivariate regression analyses between food security and its components of all the farmers shows food availability has a major impact on food security as $93 \%$ variation in food security is explained by variation in food availability. The study suggested that priority should be accorded for creating rural employment opportunities, providing infrastructure for increasing production and creating awareness of education for long term sustainability of food security in the study area.
\end{abstract}

Key words: Food security components, Food security, India

\section{Introduction}

Food security concept has experienced an evolutionary change during the last 50 years. In the nineteen fifties, the focus was on food availability in the market as well as in the households. Later in the seventies, it became apparent that food availability alone cannot ensure food security; accessibility to balanced diet will be determined by purchasing power and there may be variation in livelihood opportunities. If food is available and people have access to it, clean drinking water, primary health care, primary education and environmental hygiene will determine the biological absorption and utilization of consumed food. Recently it is observed that even if physical and economic access to food is assured, long-term sustainability of food security systems will be determined by the ecological factors (Swaminathan, 2001).

The world Food conference convened by FAO (1974) gave the call that no child, woman and man should go to bed hungry and no human beings physical and mental capabilities should be stunted by malnutrition. According to FAO's annual hunger report (2009) nearly 850 million people all over the world are undernourished. About $96 \%$ of such persons are living in developing countries (FAO 2006). In Asia and the Pacific 
region, an estimated 642 million people are suffering from chronic hunger. India is home to $42 \%$ of the world underweight children and improvement in this indicator since 1990 has been far too slow to suggest that the Millennium Development Goal target of $26.8 \%$ by 2015 can be achieved (Millennium Development Goals 2007). All these testify to failure to achieve global food security. Currently food security has been greatly undermined globally resulting in food rationing in the developed countries and food riots in the developing countries of Asia and Africa.

One of the major developmental objectives of India has been providing food security. India achieved self-sufficiency in food grains in the 1970's and has sustained it since then but the achievement of food security has not been attained at the household level. Endemic mass-hunger coexisting with the mounting food grain stocks and thus rendering India into paradoxical situation. Though the Food Corporation of India (FCI) has ample of food grain stocks available with it, millions of people are underfed and another millions are at the verge of starvation. The M. S. Swaminathan Research Foundation and World Food Program have recently brought out a food insecurity Atlas of rural India (Swaminathan 2001). According to the atlas, Bihar is the extremely food insecure state of India. This is in conformity with the findings of the atlas of rural Bihar published by the Institute of Human Development in collaboration with the World Food Program (2009). It is therefore necessary that potential and existing situation of each part of the state should be evaluated with respect to socio economic indicators.

Household food security is not only influenced by the availability of food but also by the capacity of household to purchase the food. Now food is available at global and national level but poverty is one of the major problems affecting food security at household level. Food abundance will not help poor households unless these have access to that food. (Vanugopal, 1992). Food access is influenced by the food availability through the behavior of prices. Accessibility also depends on their household production and ability to purchase food from the market. The purchasing power of the people in turn is determined by the entitlement of the households and entitlement defines the economic activities carried by the people to generate income and ensuring the objective of food security (Omonona et al, 2007). Food security of the people is further affected by food safety. For food security it is necessary that the people must have food safety. Clean drinking water, environmental hygiene, primary health care and elementary education determine food safety. Ecological factors beside food availability and accessibility also determine sustainable food security system (Swaminathan, 2001). Household food security is the application of food security concept to the family level with individuals within households as the focus of concern (FAO 2001). The measurement of household food security is typically made by interviewing the member of the households and analyzing their reported experience.

\section{Materials and methods}

\subsection{Case Study Area: Vaishali District, India}

Vaishali district is located between the latitudes of $25^{\circ} 29^{\prime} \mathrm{N}$ and $26^{\circ} 10^{\prime} \mathrm{N}$ and between $85^{\circ} 8^{\prime} \mathrm{E}$ and $85^{\circ} 33^{\prime} \mathrm{E}$ longitude with the area of around $2036 \mathrm{Sq}$. Km. The district is bounded by river Ganga in the south and Gandak in the west and surrounded by Muzaffarpur district in the north and Samastipur in the East. There are three sub divisions of the district viz.Hajipur, Mahnar Bazar, Lalganj and 16 blocks viz. Vaishali, 
Paterhi belsar, Lalganj, Bhagwanpur, Goraul, Chehrakalan, Mahua, Jandaha, Rajapakar, Raghopur, Biddupur, Desri, Sahdai Buzrug, Mahnar.

The district has 1638 revenue villages and 291 Gram Panchayat (Village Parliaments). The principle soil orders throughout the region are entisols and inceptisols. Vaishali district generally enjoys a bracing and healthy climate with three well marked seasons viz winter, summer and rainy season. January is the coldest month when the mercury drops below $5^{\circ} \mathrm{C}$. The summer heat is intense and reaches above $40^{\circ} \mathrm{C}$ in the month of May and continues until the rain comes. The average annual rainfall in this area ranges from 100 $\mathrm{cm}$ to $150 \mathrm{~cm}$. The land being fertile, no area has been left for wild growth and the entire district is devoid of any forest. The district is famous for banana cultivation. The district has a total population of 2.7 million with decadal growth rate of $26.67 \%$. Population density is 1335 persons/sq.km. The proportion of scheduled caste to the total population is $21 \%$. Sex ratio of total population is 920 . Literacy rate is $50.49 \%$ (Census of India, 2001). Economic classification of population shows that $31 \%$ are cultivators, $42 \%$ are agricultural labourers, $4.0 \%$ are household industry workers and $23.0 \%$ are other workers (Census of India, 2011).

Agriculture is still an important sector in Bihar since it contributes about $16 \%$ to State Gross Domestic Product and provides employment to about $70 \%$ of working force in rural area. The state is characterized by small land holders in the country. More than 90 $\%$ of farm households belong to marginal farm category (less than 1 ha land) but own about $44 \%$ of cultivated land in Bihar. During 2004-11, State Agricultural GDP grew at the annual growth rate of $2.7 \%$. But the growth has not been sustainable, mainly due to floods in $2007 \& 2008$ and draughts in $2009 \& 2010$. The development of agriculture in the state has lagged behind due to constraints like practicing of traditional methods of cultivation, lack of access to modern technology, low productivity, inadequate capital formation and low investment, inadequate irrigation facilities, uneconomic size of holdings, widespread illiteracy among farmers, helpless victims of natural calamities, inefficient management of resources, poor performance of extension education and inadequate agricultural marketing facilities. A number of central sponsored projects have already been initiated in the State but they have not yielded the desired results.

\subsection{Database and analytical technique}

Data for examining food security situation were collected from primary sources through field surveys, household surveys, and interviews with farmers and discussion with government officials. The field work was done by the researcher during 2012-13. For getting accurate information, the farmers' households were visited frequently. A questionnaire was designed to collect the relevant information related to food security and sustainable agriculture in Vaishali district. Sufficient care was taken to make the questionnaire communicable to the respondents. The respondents for household questionnaire were the heads of the households.

The sample design adopted was stratified random sampling. The first stage consisted of selecting villages from the study area. Each block of the district was divided into high, medium and low population villages. From each of these strata I village was selected randomly. From each block (The district is divided into 16 blocks) 3 villages were selected randomly. In this way 48 villages were selected from the whole district. Figure 1 is showing the location of the sampled villages in Vaishali district. 
The second stage consisted of selecting households from 48 villages. This was also done with the help of stratified random sampling technique. In this case, the criteria for judging the stratum were the farm size categories. From each farm size category, 5 households were selected randomly. Therefore, from each village 240 households were to be surveyed but in some villages there were no large farmers while in some village medium farmers were not found. There were only 26 large farmers and 213 medium farmers. Therefore, from the expected sample size of 1200 households, 214 households of large farmers and 27 households of medium farmers were deducted and in this way study is based on 959 farmers' households.

Figure 1: Location of sampled villages in Vaishali district

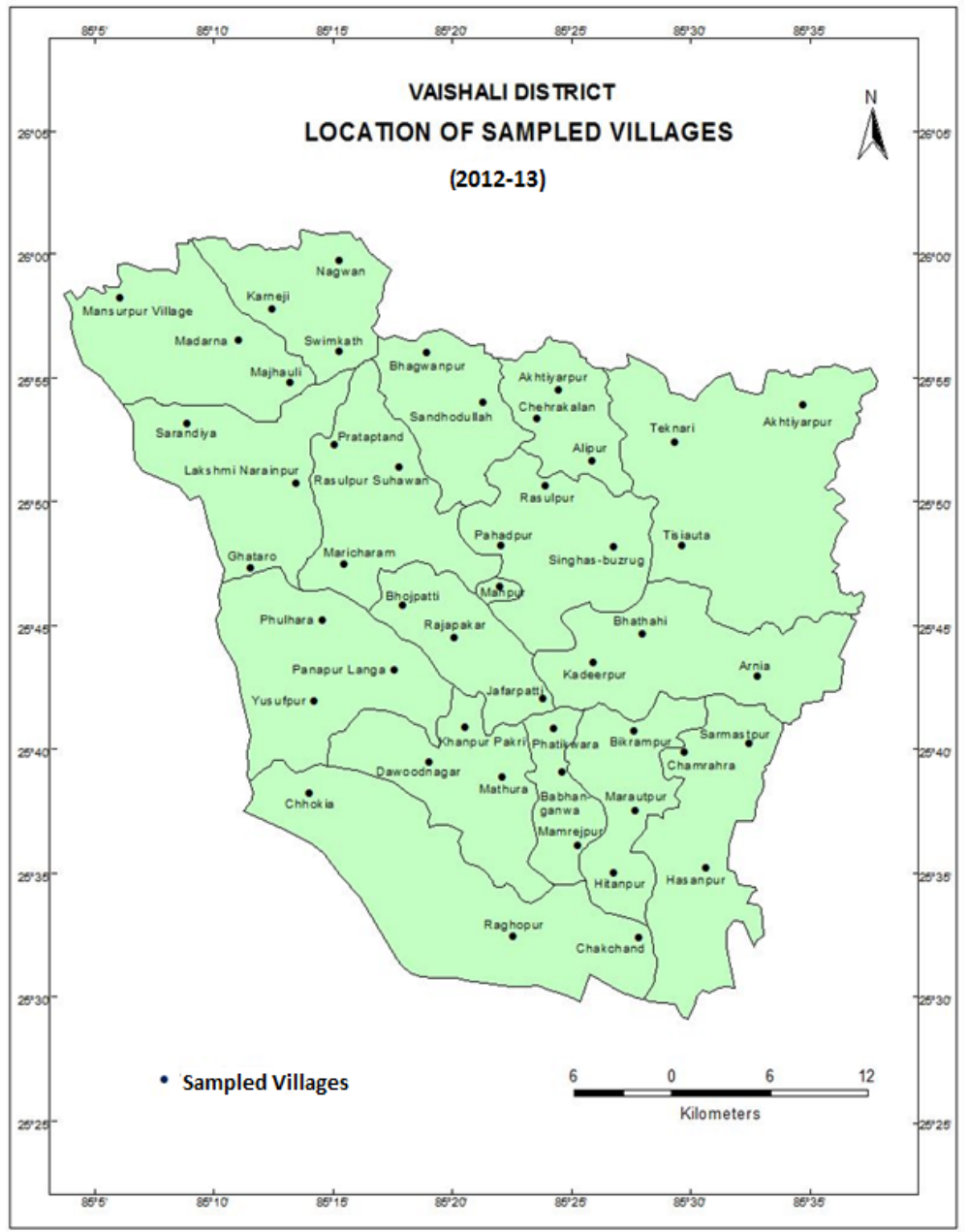

For the calculation of food security composite index at block and farm level, division by mean method has been used. Here the mean value for each indicator is calculated. Then the value of each block/ household is divided by the corresponding mean value of independent indicators in case of positive indicator. The outcome is known as Scale Free Value (SFV). 
Let SFV be the index for the $\mathrm{i}^{\text {th }}$ component of SFV related to the $j$ th entity (households in a village context, districts in a state context, regions in a national context, and nations in a global context) and let $\mathrm{X}_{\mathrm{ij}}$ be the value of the variable representing the $\mathrm{i}^{\text {th }}$ component of SFV related to the $j^{\text {th }}$ entity. Then the index for the $i^{\text {th }}$ component of SFV of the $j^{\text {th }}$ entity can be calculated as follows:

$$
S F V=\frac{X_{i j k}}{\sum X_{i j k} / N}----------(1)
$$

Where I = Variables $(1,2,3-----------------, ~ I)$

$\mathrm{J}=$ Components $(1,2,3$-------------- $\mathrm{J})$

$\mathrm{K}=$ households $(1,2,3-$

In case of negative indicator the mean of an indicator is divided by the corresponding value of each block. The outcome is known as Scale Free V alue (SFV).

$$
\begin{gathered}
S F V=\frac{\sum X_{i j k} / N}{X_{i j k}}---------(2) \\
F S C I=S F V_{1} * 1 / n+S F V 2 * 1 / n+S F V 3 * 1 / n+----S F V_{n} * 1 / n-----(3)
\end{gathered}
$$

Where, $\mathrm{n}=$ the number of indicators used in calculation of a component.

\subsection{Rationale for selection of indicators}

Food availability is expressed as the existence of food stocks for consumption which may be available from own production or purchases from the internal market (Jrad et al., 2010). Food availability indicators were selected to holistically describe the household agricultural production and the farming processes essential for it. Three essential indicators were included for assessing food availability. Per capita food grain production has been chosen since the primary occupation of farmers is agriculture. They are heavily relied on their own production for meeting food requirements. The availability of cultivable land shows the potential to grow food and make it available to the farmer's household. Though land is a resource that is finite in supply but at the same time it the availability of land is a major factor limiting the agricultural growth. Irrigation is prerequisite for producing crops. Its timely and assured supply determines the stability of the agricultural production which in turn is augmented with food availability.

If availability of food as a component of food security is the prerequisite for food security, food accessibility may be considered as the axis of food security around which all the economic activities revolves either by growing food directly under primary economic activity or through earning money finally to buy food through secondary or tertiary economic activity. A central issue here is to procure food and have individual entitlement. It is therefore necessary to assess that every farmer household should have potential to produce in adequate quantity for all family members or has entitlement to purchase it from the market. Proportion of expenditure to the total household expenditure, food poverty, low energy availability, household dietary diversity score, 
months of household food provisioning indicators were computed to examine the state of food accessibility among the sampled farmers.

High share of income spent on food items is related to poor condition of the households. Higher the expenditure on food items, higher the poverty in the household. Food expenditure is computed by summing the expenditure on all individual food items bought in one month and the price of food consumed from home production. Food Poverty (FP) in the household is prevalent when the household is not in position to purchase a recommended nutritional diet. It is the ratio of money spent to purchase the diet to the cost of a basic food basket. The cost of food basket for the sampled households is calculated on the basis of food basket (planning commission, 2011), which comes out to the cost for $2400 \mathrm{kcal}$ per person per day which is 781 rupees/person/month. This ratio can be expressed as the proportion of the food expenditure to the nutritionally balanced diet (Rose and Charlton 2002). Low energy availability (LEA) is experienced when the energy available in food supplies is less than the sum of recommended energy intakes for each adult member. The numerator of the LEA was computed as the sum of the energy available in the food consumed on daily and weekly basis reported by the household. The denominator is a sum of the daily recommended energy intakes for an adult male member of the household. If the household scored $<1$ value, it is said to be low energy availability household (Cock et al. 2013; Rose and Charlton 2002).

The Household Dietary Diversity Score (HDDS) reflects diversity in food items consumed by the household. The numbers of affirmative answers regarding consumption of nine food items at least once in a week were summed. The food items included cereals, pulses, root and tubers, green vegetables, seasonal and local fruits, meat, egg, fish, milk and curd. The score ranges between 0 and 9. Higher score reflects the combination of nutritional needs for a healthy diet. Months of Adequate Household Food Provisioning (MAHFP) measures extents of months of the past year a household was not able to provide members with enough food (Swindale and Bilinsky 2007). A MAHFP score ranges between 0 and 12 .

How the accessed food is being utilized is a big matter of concern. Without rational food utilization the status of food security cannot be achieved. Proper or optimum use of accessed food as a source of energy for healthy and active life depends upon many factors. Availability of safe drinking water within the household, literacy, primary health care, child mortality rate, span of life and proper sanitation facilities have been chosen for assessing proper utilization of the food of the sampled farmers. Clean drinking water is one of the basic needs and without safe drinking water it would be difficult to release energy from the accessed food by the digestive system along with clean hygienic environment, medical facilities, etc. Literacy is considered as one of the important factors related to proper use of accessed food, so as to get the maximum possible benefit. It is expected that a literate person would be more aware of the nutritional aspects along with cleanliness and hygienic surrounding. These persons are expected to realize the importance of timely vaccination of their children. All these could aggregate to a healthy child and finally a healthy society. One of the suitable methods to measure food absorption is through outcome indicators like child mortality and maximum life span. Child mortality rate (CMR) has been chosen as an outcome indicator of food utilization. It is a fact that high CMR not only reflects the inappropriate child up keeping but also an insufficient prenatal and postnatal care of the mother by the health practitioner and also 
the family members. Timely vaccination could lower the rate of child mortality by safe guarding the child from a number of life threatening diseases and infections.

Table 1: Indicators used to assess household food security in Vaishali district

\begin{tabular}{|c|c|c|c|c|c|c|c|c|c|c|c|c|c|}
\hline \multirow[b]{2}{*}{$\begin{array}{l}\text { Farmers' } \\
\text { Category }\end{array}$} & \multicolumn{3}{|c|}{$\begin{array}{c}\text { Food } \\
\text { Availability Indicators }\end{array}$} & \multicolumn{5}{|c|}{$\begin{array}{l}\text { Food Accessibility } \\
\text { Indicators }\end{array}$} & \multicolumn{5}{|c|}{$\begin{array}{l}\text { Food Utilization } \\
\text { Indicators }\end{array}$} \\
\hline & 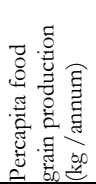 & 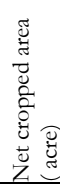 & 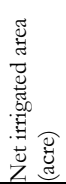 & 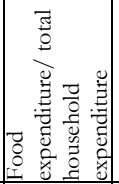 & $\begin{array}{l}\text { E. } \\
0 \\
0 \\
0 \\
0 \\
0 \\
0 \\
0 \\
\end{array}$ & 蒫 & 会 & 位 & 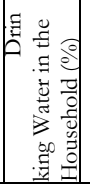 & 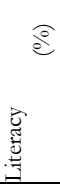 & 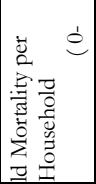 & 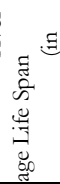 & 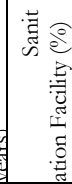 \\
\hline Large & 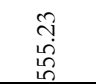 & 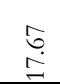 & 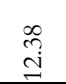 & 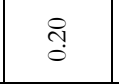 & $\stackrel{\Re}{-}$ & $\stackrel{\text { 管 }}{\rightarrow}$ & $\stackrel{\infty}{\stackrel{\infty}{r}}$ & $\underset{\substack{8 \\
i}}{+}$ & $\alpha$ & $\begin{array}{l}0 \\
\infty \\
\infty \\
\infty \\
\infty\end{array}$ & $\overrightarrow{\tilde{o}}$ & $\stackrel{\overrightarrow{0}}{\overrightarrow{0}}$ & $\stackrel{8}{8}$ \\
\hline Medium & ๙ิे & $\stackrel{+}{=}$ & సે & $\stackrel{\overbrace{}}{0}$ & $\stackrel{\infty}{\infty}$ & $\stackrel{\leftrightarrow}{\sim}$ & $\underset{\substack{+r}}{2}$ & $\underset{i}{8}$ & $\approx$ & $\begin{array}{l}\qquad 0 \\
\infty \\
\infty \\
\infty\end{array}$ & in & å. & 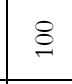 \\
\hline $\begin{array}{l}\text { Semi- } \\
\text { medium }\end{array}$ & $\begin{array}{l}\overrightarrow{.} \\
\infty \\
\infty \\
\rightarrow\end{array}$ & શิ & in & $\stackrel{0}{0}$ & $\stackrel{\leftrightarrow}{-}$ & $\stackrel{\overbrace{}}{\rightarrow}$ & $\stackrel{2}{0}$ & $\underset{i}{8}$ & $\stackrel{\circ}{\circ}$ & $\underset{\infty}{\infty}$ & กิ? & 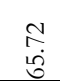 & $\nsubseteq$ \\
\hline Small & $\begin{array}{l}4 \\
\text { in } \\
\infty \\
\infty\end{array}$ & $\stackrel{\text { f }}{\text { i }}$ & बे. & $\stackrel{m}{0}$ & $\stackrel{\substack{\not \\
0}}{\circ}$ & $\stackrel{\infty}{\stackrel{\infty}{\rightarrow}}$ & $\stackrel{\substack{n \\
\stackrel{n}{+}}}{+}$ & 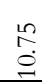 & in & $\overrightarrow{\tilde{o}}$ & $\stackrel{8}{\circ}$ & $\begin{array}{l}\infty \\
\stackrel{\circ}{i} \\
i\end{array}$ & n \\
\hline Marginal & $\begin{array}{l}\text { ले } \\
\infty \\
\text { ते }\end{array}$ & $\exists$ & $\stackrel{g}{\text { - }}$ & $\stackrel{n}{\stackrel{n}{0}}$ & S్ర & $\stackrel{q}{\rightarrow}$ & $\stackrel{+}{+}$ & $\stackrel{\stackrel{n}{m}}{n}$ & $\stackrel{m}{\sim}$ & 辛 & $\stackrel{\overbrace{}}{0}$ & 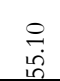 & $\stackrel{\infty}{+\infty}$ \\
\hline
\end{tabular}

Table 2: Indices used to assess household food security in Vaishali district

\begin{tabular}{|c|c|c|c|c|c|c|c|c|c|c|c|c|c|}
\hline \multirow{2}{*}{ 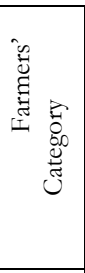 } & \multicolumn{3}{|c|}{$\begin{array}{c}\text { Food } \\
\text { Availability Indices } \\
\end{array}$} & \multicolumn{5}{|c|}{ Food Accessibility Indices } & \multicolumn{5}{|c|}{ Food Utilization Indices } \\
\hline & 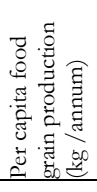 & 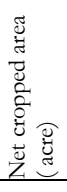 & 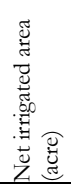 & 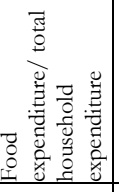 & 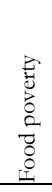 & 畄 & 狊 & 属 & 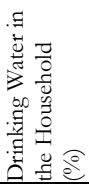 & 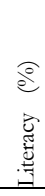 & 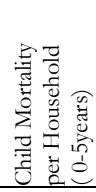 & 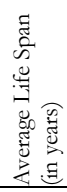 & 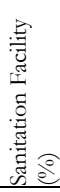 \\
\hline 总 & $\overrightarrow{\dot{m}}$ & 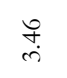 & 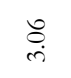 & in & 贲 & $\stackrel{\infty}{\stackrel{\infty}{+}}$ & $\underset{\text { N̦}}{ }$ & $\stackrel{\rho}{\mathrm{i}}$ & $\stackrel{?}{g}$ & 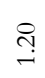 & F: & o. & $\stackrel{\overbrace{}}{\leftrightarrows}$ \\
\hline 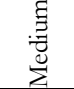 & $\stackrel{\overbrace{}}{\sim}$ & d. & సે & $\stackrel{+}{i}$ & $\stackrel{\vec{n}}{\rightarrow}$ & $\stackrel{\Xi}{\rightarrow}$ & $\stackrel{\infty}{\rightarrow}$ & $\stackrel{\infty}{\stackrel{\sim}{\oplus}}$ & $\stackrel{\circ}{n \rightarrow ~}$ & $\stackrel{\bar{I}}{\rightarrow}$ & $\stackrel{?}{0}$ & $\stackrel{8}{\circ}$ & 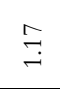 \\
\hline 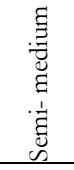 & $\stackrel{t}{\circ}$ & $\stackrel{\infty}{\infty} \underset{\infty}{\infty}$ & స్త. & $\stackrel{\substack{n \\
\rightarrow}}{\rightarrow}$ & $\stackrel{\infty}{\rightarrow}$ & â. & กิ & $\stackrel{5}{s}$ & $\stackrel{\infty}{+}$ & 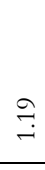 & $\stackrel{\circ}{\circ}$ & 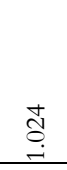 & 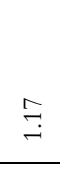 \\
\hline 医 & $\stackrel{0}{0}$ & 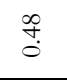 & fै. & $\hat{\sigma}$ & $\vec{i}$ & $\stackrel{\circ}{\circ}$ & $\stackrel{\infty}{\circ}$ & s. & $\stackrel{\infty}{\infty}$ & oे & $\stackrel{n}{0}$ & 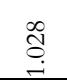 & $\stackrel{\leftrightarrow}{\rightarrow}$ \\
\hline 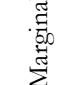 & $\stackrel{n}{0}$ & तิ & त̂̀ & $\stackrel{\infty}{\infty}$ & fे & $\stackrel{n}{\stackrel{n}{+}}$ & $\stackrel{0}{N}$ & $\stackrel{\substack{\infty \\
\infty}}{\infty}$ & సิ ฮิ & के & दे & $\begin{array}{l}\infty \\
\stackrel{\infty}{\infty} \\
\infty\end{array}$ & 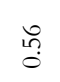 \\
\hline
\end{tabular}


Maximum life span is also considered as an outcome indicator of food utilization. High maximum life span could be a function of good nutritional status throughout the life span and utilization of proper medical facilities. Maximum life span reveals many things related to quality of life. A high maximum life span may be due to good quality of life whereas low life span may be related to improper or low quality of life where food is inseparable. Environmental hygiene and sanitation is a necessary condition to improve food absorption (Swaminathan 2001).

\section{Results and Discussion}

\subsection{Relative Performance of FSI and its Components}

Variation and relative performance of Food Security Index (FSI) and its components indices (Food availability index, food accessibility index and food utilization index) at the farm level are presented in Table 3. An extreme condition of food availability among the sampled farmers was observed. Large and medium farmers have high food availability while semi-medium, small and marginal farmers have low food availability (See Table 3).

Table 3: Composite indices of FA, FACC, FU and FSI

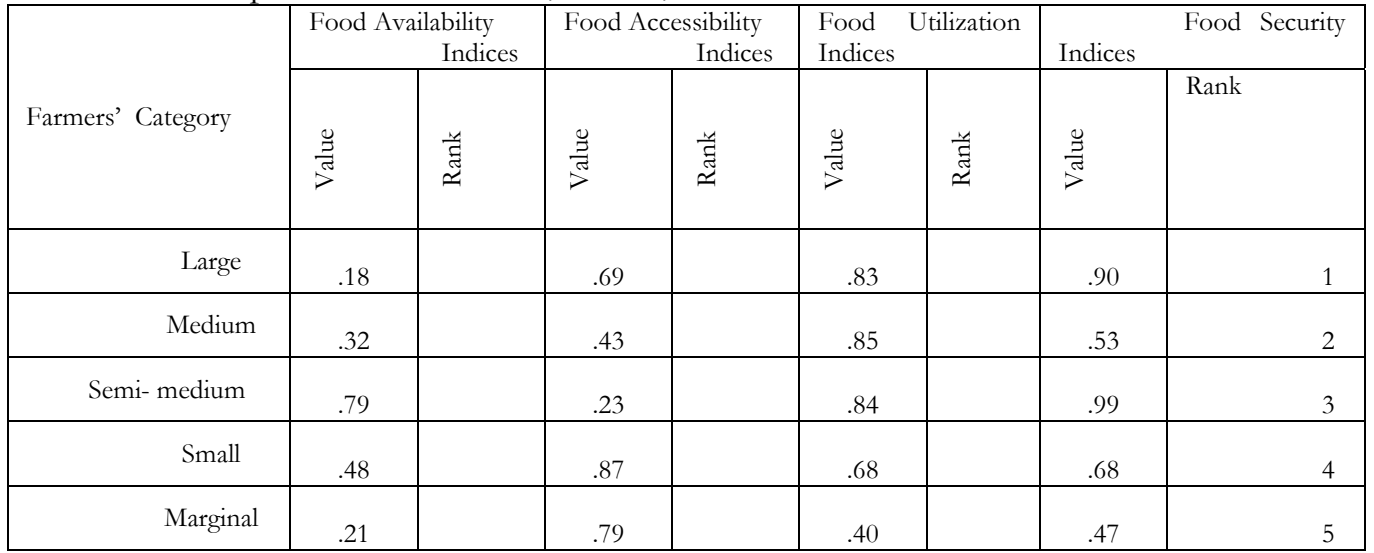

Source: Authors' calculation

Large and medium farmers have high food accessibility. These farmers enjoy high status of food accessibility due to enough food provisioning, diversity in dietary, high energy from the food supply, and adequate nutritional food basket. Low expenditure on food items also indicates towards their high food accessibility. Semi-medium farmers have moderate accessibility of food because of low energy availability, food poverty and more expenditure on food. Small and marginal farmers have low accessibility of food (Table 3). These farmers have poor performance in all the food accessibility indicators. The average proportion of expenditure on food to the total household expenditure of all the sampled farmers' household was 0.56. Among the various categories of farmers, high expenditure on food items was incurred by small and marginal farmers. The expenditure on food items was moderate in the case of semi-medium farmers while medium and large farmers spent less income on food items. Food poverty value less than 1 refers to food expenditure lesser than the price of an adequate food basket. On average sampled households have food poverty value more than 1 indicating high earnings than the standard food basket price that is 781 rupees/person/month (recommended by planning 
commission of India, 2011). Relative position among various categories of farmers shows that large, medium and semi-medium farmers spend more money than the food basket price. Energy availability value less than 1 is considered as inadequate energy intake. All the sampled farmers were having high energy availability as they were consuming more energy intake than recommended energy intakes. LEA value was lowest in the case of small farmers. The marginal farmers have large value of LEA but they consume such intake only for nine months. Secondly they take food once in a day but gain high intakes. The average dietary diversity score (HDDS) for all the farmers were 5.77. Medium farmers had the highest score (7.40) followed by large farmers (7.08). It means that even the highest ranking farmer category was not getting diversified diet whereas marginal and small farmer scored only 4.14 and 4.55 respectively. So, it is clear from this score that marginal farmer and small farmer are not getting variety of eatables needed for good health. The months of adequate household food prevalence (MAHFP) among all the sampled farmers household is 11.03. Large, medium and semi-medium farmers have adequate food round the year. Small and marginal farmers have highest MAHEP score. They face food shortage especially during lean agricultural seasons.

On an average $66 \%$ sampled farmers have drinking water facility within their households. Availability of drinking water is highly unequal among the different categories of farmers. Most of the medium, semi-medium and large farmers had drinking water facility within their houses. Nearly half of the sampled small farmers and $87 \%$ marginal farmers had to fetch water from government hand pumps located in unhygienic environment. Over all literacy rate of the sampled households is high but it was quite low among marginal farmers. The average mortality rate of children between the ages of $0-5$ years was on an average 0.62 per household.

The highest child mortality was prevalent among marginal farmers $(0.79$ per household) and small farmers ( 0.60 per household). It was found that the total sampled farmers had an average life span of 64 years. Among the various farmer categories large farmers had the highest average life span of 70 years reflecting their high resource availability. Marginal farmers had the lowest average life span at 55 years reflecting their low quality of life. On an average, 85 percent of the farmers had sanitation facilities within their households. Most of the large, medium semi-medium and small farmers have proper sanitation facilities. More than half of the marginal farmers had to defecate outside. Medium, semi-medium and large farmers have high food utilization pattern. Small farmers utilize food moderately while marginal farmers rank lowest in food utilization. All these farmers performed better in food utilization indicators. Nonavailability of drinking water in the households, low literacy and high child mortality rate among small farmers made them moderate in food utilization index. Marginal farmers rank least in all the indicators and thus are most vulnerable in food utilization.

Composite food security index based on its three components indices was computed. Relative food security index shows that large and medium farmers have high food security. Semi-medium and small farmers have moderate food security while marginal farmers have low food security.

\subsection{Extent of Food Security and its Components}

On an average an overwhelming majority of the sampled farmers $(74.7 \%)$ have low food availability. About $18 \%$ have moderate food availability and only $7.3 \%$ have high food availability. Among the various categories, it is the large farmers who have 
high food availability. Medium farmers have moderate food availability. Semi-medium, small and marginal farmers have low food availability. Within farmers' category, most of the large farmers $(77 \%)$ have high food availability; most of the medium farmers $(65 \%)$ have moderate food availability. All the small and marginal farmers have low food availability while majority of the semi-medium farmers ( $88 \%$ ) have low food availability (Table 4).

It was found that among the total sampled farmers about $68 \%$ farmers had comparatively low food accessibility, $29.4 \%$ farmers were found in medium category whereas only $2.5 \%$ household were having high food accessibility category. Relative status of food accessibility shows that large farmers have high food accessibility. Large farmers consume more energy from food than the standard set by the planning commission. The average expenditure on food in this category was only $20 \%$ of the total expenditure coupled by enough stock to support 12 months of adequate food prevalence in all the households. All these contributed to have higher food accessibility. Medium farmers have moderate food accessibility. These farmers spend slightly more on their food than the large farmers which was calculated as $30 \%$ of their total income. On the scale of food poverty this category of farmers spends about $88 \%$ more than the sufficient amount of a food basket considered by the planning commission. Semimedium, small and marginal farmers have low food accessibility. Within farmers' category most of the large farmers $(65 \%)$ and medium farmers $(81 \%)$ were having moderate food accessibility. Majority of the semi-medium (62\%), small (98\%) and marginal $(99 \%)$ have low food accessibility (See Table 4). Semi- medium category farmers were consuming around $30 \%$ more energy from food than the standard set by the planning commission. The average expenditure on food in this category was $46 \%$ of the total expenditure. The small farmers were reported of spending $73 \%$ of their total income on food. They were also unable to manage the required amount of standard food basket suggested by planning commission. Marginal farmers disclosed $75 \%$ of their total income is spent on food. The standard nutritional food basket was also low in their case. Although were not found to spend enough on food items this category was not found low in energy availability. The main source of energy of these farmers was mainly the high consumption of grains. Grains are the cheapest source of energy as well. However this energy was not all the year round. They reported of having only three to four months of adequate food provisioning.

Nearly $15 \%$ household had on average low food utilization, $24.5 \%$ sampled household were found in medium category and around $60 \%$ sampled households were in high food utilization category. Relative status of food utilization of the farmers shows that medium farmers have high utilization of food, small farmers have moderate food utilization and small farmers have low utilization of food. Within farmers' category, 99 percent medium farmers, $93 \%$ semi-medium farmers and $92 \%$ medium farmers were having high utilization of food. Nearly $52 \%$ small farmers have medium level of utilization while more than half of the marginal farmers were found in the low level of food utilization. 
Table 4: Extent of food security among the sampled farmers in Vaishali district

\begin{tabular}{|c|c|c|c|c|c|c|c|c|c|c|c|c|}
\hline \multirow[b]{2}{*}{$\begin{array}{l}\text { Farmers' } \\
\text { Category }\end{array}$} & \multicolumn{3}{|c|}{ Food Availability } & \multicolumn{3}{|c|}{ Food Accessibility } & \multicolumn{3}{|c|}{ Food Utilization } & \multicolumn{3}{|c|}{ Food Security } \\
\hline & 茴 & 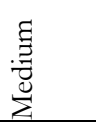 & .50 & 苂 & 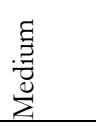 & .5 & 苂 & 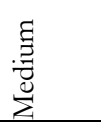 & .ే & 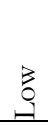 & 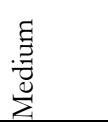 & 家卢 \\
\hline Large & & $\vec{\sim}$ & ڤे & & ثூర & $\begin{array}{l}\stackrel{0}{*} \\
\stackrel{+}{n}\end{array}$ & & $\stackrel{r}{r}$ & $\stackrel{\text { an }}{a}$ & ' & ஸे & $\begin{array}{l}\vec{b} \\
\Omega\end{array}$ \\
\hline Medium & $\stackrel{\infty}{\stackrel{\bullet}{\ominus}}$ & 요 & $\begin{array}{l}\stackrel{n}{n} \\
\ddot{\sim}\end{array}$ & $\stackrel{\vec{g}}{\vec{g}}$ & $\frac{N}{\infty}$ & in & 1 & $\hat{o}$ & $\stackrel{\circ}{\circ}$ & ' & 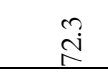 & 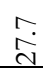 \\
\hline $\begin{array}{l}\text { Semi- } \\
\text { medium }\end{array}$ & $\begin{array}{l}\hat{\infty} \\
\infty \\
\infty\end{array}$ & $\stackrel{?}{\rightleftarrows}$ & & $\begin{array}{l}\tilde{\sigma} \\
\text { îj }\end{array}$ & $\begin{array}{l}\text { N̦} \\
\text { ñ }\end{array}$ & $\stackrel{N}{\sim}$ & $\stackrel{n}{n}$ & $\stackrel{\sim}{+}$ & $\stackrel{m}{\Omega}$ & থু & $\begin{array}{l}\infty \\
\stackrel{\infty}{n}\end{array}$ & \\
\hline Small & 8 & & & 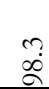 & 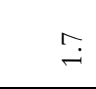 & ' & $\dot{\sigma}$ & $\begin{array}{l}n \\
\text { ñ } \\
\text { ñ }\end{array}$ & $\stackrel{r}{\vec{g}}$ & 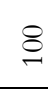 & & \\
\hline Marginal & $\stackrel{\sim}{\circ}$ & & & $\stackrel{\circ}{\circ}$ & $\stackrel{\text { กิ }}{\circ}$ & , & $\begin{array}{l}\stackrel{0}{1} \\
\stackrel{1}{n}\end{array}$ & $\stackrel{\vec{m}}{\circ}$ & $\stackrel{+}{\circ}$ & 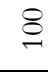 & & \\
\hline All Farmers & 竎 & $\begin{array}{l}0 \\
\infty \\
\rightarrow\end{array}$ & $?$ & $\overrightarrow{\circ 0}$ & $\dot{\curvearrowright}$ & $\stackrel{n}{i}$ & $\stackrel{n}{n}$ & 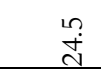 & $\stackrel{1}{8}$ & : & $\begin{array}{l}\ddot{\lambda} \\
\ddot{\lambda}\end{array}$ & $\infty$. \\
\hline
\end{tabular}

\section{Source: Authors' calculation}

Table 5: Coping strategies adopted by the sampled farmers' households in Vaishali district

\begin{tabular}{|c|c|c|c|c|c|c|c|c|c|}
\hline \multirow[b]{2}{*}{$\begin{array}{l}\text { Farmers' } \\
\text { Category }\end{array}$} & \multicolumn{9}{|c|}{ Coping Strategies } \\
\hline & 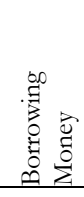 & 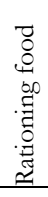 & 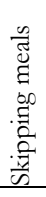 & 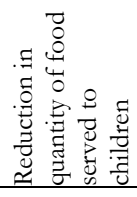 & 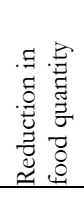 & 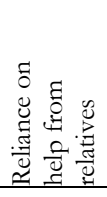 & 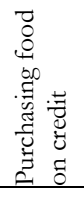 & 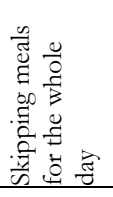 & 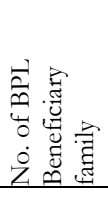 \\
\hline Large & - & - & & & - & - & & - & \\
\hline Medium & - & & - & - & - & - & & - & \\
\hline $\begin{array}{l}\text { Semi- } \\
\text { medium }\end{array}$ & $\begin{array}{l}\infty \\
\stackrel{\infty}{+} \\
\stackrel{\text { I }}{\sim}\end{array}$ & $\stackrel{\sim}{a}$ & , & ' & 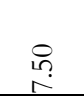 & ' & $\begin{array}{l}\infty \\
\stackrel{\sim}{?} \\
a\end{array}$ & ' & \\
\hline Small & in & તิ่ & $\begin{array}{l}\infty \\
\text { ì } \\
\text { in }\end{array}$ & ' & 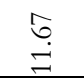 & $\begin{array}{l}\text { in } \\
\text { הn }\end{array}$ & 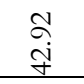 & $\stackrel{F}{\underset{f}{f}}$ & $\begin{array}{l}\infty \\
\infty \\
\dot{n}\end{array}$ \\
\hline Marginal & $\begin{array}{l}\infty \\
\stackrel{\infty}{+} \\
\stackrel{+}{2}\end{array}$ & $\begin{array}{l}\stackrel{1}{\kappa} \\
\infty \\
\infty \\
\infty\end{array}$ & $\begin{array}{l}\infty \\
\stackrel{1}{6}\end{array}$ & $\begin{array}{l}\text { กิ } \\
\text { กi }\end{array}$ & $\begin{array}{l}\infty \\
\stackrel{\infty}{n} \\
\stackrel{+}{N}\end{array}$ & $\ddot{m}$ & $\stackrel{m}{m}$ & $\stackrel{m}{\sim}$ & 号 \\
\hline
\end{tabular}


Table 6: Bivariate regression between food security and its components among the sampled farmers in Vaishali district

\begin{tabular}{|c|c|c|c|c|c|c|}
\hline \multirow{2}{*}{$\begin{array}{l}\text { Farmers' } \\
\text { Category }\end{array}$} & \multicolumn{2}{|c|}{ Food Availability } & \multicolumn{2}{|c|}{ Food Accessibility } & \multicolumn{2}{|c|}{ Food Utilization } \\
\hline & $\begin{array}{l}\text { Beta } \\
\text { Coefficient }\end{array}$ & $\mathrm{R}^{2}$ & $\begin{array}{l}\text { Beta } \\
\text { Coefficient }\end{array}$ & $\mathrm{R}^{2}$ & Beta Coefficient & $\mathrm{R}^{2}$ \\
\hline Large & 0.786 & .619 & - & & - & - \\
\hline Medium & 0.944 & .892 & 0.373 & .139 & - & - \\
\hline $\begin{array}{l}\text { Semi- } \\
\text { medium }\end{array}$ & 0.782 & .611 & 0.507 & .257 & 0.444 & 0.197 \\
\hline Small & 0.609 & .371 & 0.261 & .068 & 0.773 & 0.597 \\
\hline Marginal & 0.309 & 0.096 & 0.531 & .282 & 0.748 & 0.559 \\
\hline All Farmers & $0.967^{* *}$ & .936 & $0.846^{* *}$ & .716 & $0.693^{* *}$ & 0.480 \\
\hline
\end{tabular}

${ }^{* *}$ Correlation is significant at the 0.01 level (2-tailed). Dependent V ariable: Food Security Index

Large farmers have highest average maximum life span and availability of primary health care and sanitation facilities within their households contributing to clean and hygienic surroundings. All these factors have resulted into proper utilization of food among large farmer category. High food utilization level of medium category farmer is attributed to the fact that this category of farmers was found to have the highest drinking water facility within the household, highest literacy rate, high maximum life span and $100 \%$ sanitation facility within the household premises. Small farmers lack safe drinking water and sanitation facility. Marginal farmers were found to be deprived of many basic facilities and amenities mainly drinking water. Only $13 \%$ population had drinking water within their household the rest population had to depend on government sources or nearby water bodies. Marginal farmers were found to have literacy level as low as $41.5 \%$, highest child mortality per household and lowest sanitation facility. All these factors aggregated to result in $90 \%$ sampled household in low food utilization come from this very category.

Over all most of the sampled farmers (61\%) were having low food security, $29 \%$ moderate food security while only $8.7 \%$ have high food security. Relatively large farmers have high food security. Medium farmers have moderate food security. Small and marginal farmers have low food security. The extent of food security within farmers' category shows that most of the large farmers $(96 \%)$ have high food security; about 72 $\%$ medium farmers and more than half of the semi-medium farmers have moderate food security whereas all the small and marginal farmers were found to have low food security.

Semi- medium, small and marginal farmers lack food security and therefore they adopted different means of ensuring their food security. Most of the semi medium farmers borrow money, ration food, purchase food on credit and reduce the quantity of food intake. The condition of small and marginal farmers is worse than the semi medium farmers. The majority of small farmers either borrow money or rationing food and apart from it many households skip meals, reduce in quantity of food intake, rely on relatives for help, and purchase food on credit, skip meal for whole day and take help from below poverty line beneficiary programs. Marginal farmers are the poorest and rely mostly on the coping strategies to meet their food requirements. In marginal farmers majority rely on borrowing money, rationing food, skipping meal, avail BPL benefits and $2.5 \%$ of 
them have to even reduce the meal given to their children. Apart from this many households reduce in their quantity of food intake, skip meals and rely on their relatives for help as a measure to cope with food insecurity.

To find out the relationship between food security and its components, Karl Pearson's correlation was derived. The analysis shows that there exists significant, positive and very strong correlation between food security and its three components. Bivariate regression analysis revealed that the food security index as dependent variable and its three components as independent variables were significant at $99 \%$. The value of beta coefficient was highest (0.967) with highest value of $\mathrm{R}^{2}(0.936)$ in the case of food availability. Thus it can be inferred that food availability has a major impact on food security among all the components as $93.6 \%$ of variation in food security is explained by variation in food availability. Karl Pearson and bivariate regression analysis were carried out in order to assess the most significant components of food security and their influence on food security within farmers' category. The analysis shows that food availability has major influence on food security of large, medium and semi-medium farmers. Food security of small farmers is influenced by variation in food availability and food utilization while variation in food utilization and food accessibility influenced food security of marginal farmers.

\section{Policy Implications}

Large farmers rank first in food security index. These farmers are advance farmers having ideal conditions for sustainable food security. Medium and semi-medium farmers have moderate conditions for sustainable food security. Similarly small and marginal farmers showed low performance in food security index. These farmers are depressed sections of the farmers' category. Small and marginal farmers require urgent attention for sustaining food security in the study area. All these farmers require immediate attention for improving food availability, accessibility and food utilization. Attempts should be made to increase irrigation facilities. Public distribution system should be facilitated to enhance months of adequate food provisions. Non-agricultural employment and dairy support should be extended to cop up with food poverty and to increase diversity in food items and calorie intake. Provisions should also be made to increase literacy rate. Drinking water facility, sanitation facility and primary health centres should be made available for proper utilization of consumed food. Medium and semimedium farmers should be encouraged to diversify crops. Agricultural inputs at subsidized rates should be provided to them. Irrigation facilities also accord priority for increasing agricultural production. Large farmers also require policy interventions for long term sustainability of food security among them. Awareness of diversity in food should be made to increase nutritional level. Government is supplying essential commodities like wheat, rice, sugar, edible oils, kerosene and soft coke at below market price to consumer but it is benefiting marginally to the poor or marginal farmers. Though all the sampled marginal farmers were below poverty line beneficiaries but they were not receiving food grains regularly through this scheme. To eradicate the problem of food insecurity government should implement poverty alleviation programmes and wage employment programmes in the study area. The farmers should be provided technical assistance to develop equipments, to improve agriculture efficiency and competitiveness especially in value addition and post harvesting technologies. Awareness 
about low cost nutritious food items and availability of good grains through PDS should be strengthened. Non-governmental organization and welfare societies can play an important role in these processes. Awareness about minimum support prices for agricultural produce should be increased and loans/interest should be waive off in the time of agrarian distress. Awareness about low-cost, low risk, high nutrition, holistic and sustainable farming system should be created to ensure food security.

\section{Conclusion}

The study concludes that wide variation in food security and its three components i.e. food availability, food accessibility and food utilization exist among the sampled farmers. The food security composite index at household level implied that large and medium farmers had high food security, semi-medium farmers had moderate food security while small and marginal farmers were having low food security status. Several government programs have been running and providing food grains to increase their food availability e.g. Antodaya Ann Yojana, Annapurna Yojana, mid day meal scheme, etc but the analysis has revealed that the condition of small and marginal farmers is still very poor. Hence there is an urgent need of policy intervention to increase the production through improved agricultural techniques and adequate inputs.

Food accessibility analysis of the sampled farmers revealed the same trend as in the food availability but the intensity of low status was found more in food accessibility. Within farmers' categories large farmers had high food accessibility; medium farmers were having moderate food accessibility while semi-medium, small and marginal farmers were having low food accessibility. Insufficient food provision, non diversity in diet, low energy from the food supply, and inadequate nutritional food basket were held responsible for low food accessibility among semi-medium, small and marginal farmers while low energy availability was found as the main reason for moderate food accessibility among medium farmers. It was also found that though large farmers had high food accessibility still they had low diversity in their diet. Low food accessibility among semi-medium, small and marginal farmers is because of the vicious circle of poverty in which these farmers are trapped. Therefore, it is imperative to increase food accessibility especially for small and marginal farmers. These farmers should be provided employment opportunities through rural work programmes. Loan at low interest rate should be provided for small enterprises. General awareness about low cost nutritious food items and diversity in their diet should be increased among them.

Large, medium and semi-medium farmers were having high food utilization whereas condition of small and marginal farmers were appalling because of low literacy, poor drinking water and sanitation facilities, high child mortality and low life span. Though government has initiated various programs for better housing, sanitation and safe drinking water facilities for raising the living standard of rural masses but the situation remain the same. Hence, there is urgent need to improve educational facilities, providing safe and adequate drinking water, proper sanitation facility and health care centers. Implementation and regular monitoring of existing programmes is necessary. It is also needed to make farmers aware of their rights and programmes promulgated in their areas. Regression analysis between food security and its components revealed that food availability has major influence on food security among all farmers. Among various categories of farmers, food availability was the most influential component of food 
security among large, medium and semi-medium farmers while food utilization was found the most influential component among small and marginal farmers. Hence the study calls immediate policy intervention to ensure food security in the study area.

\section{References}

Census of India, 2011. Office of the Registrar General and Census Commissioner, Ministry of Home Affairs, Government of India.

Cock, et al (2013): "Food Security in rural areas of Limpopo province South Africa", Food Security, 5: 269-282

FAO (1974): "The State of food insecurity in the world", Rome: Food and Agriculture Organization of the United Nations.

FAO (2001): "The State of food insecurity in the world", Rome: Food and agriculture Organization of the United Nations.

FAO (2006): Eradicating World Hunger- taking stock ten years after the World Food Summit. The State of food insecurity in the world. Rome: Food and Agricultural Organization of the United Nations.

Jrad, S., Nahas, B., Baghasa, H. (2010): "Food Security Models, Ministry of Agriculture and Agrarian Reform”, National Agricultural Policy Center. Policy Brief No 33. pp.32. Syrian Arabic Republic.

MDG. (2007): The Millennium Development Goals: Progress in Asia and the Pacific. Bangkok, Thailand: ESCAP/ADB/UNDP. 2007. Available from: http://www.mdgasiapacific.org.

Omonona, B. T. and Agoi, G. A. (2007): "An Analysis of Food Security Situation among Nigerian Urban Households: Evidence from Lagos State, Nigeria", Journal of central European Agriculture, Vol. 8, No. 3, pp. 397- 406.

Planning Commission (2011), Report of the Expert Group to Recommend the Detailed Methodology for Identification of Families Living Below Poverty Line in the Urban Areas, Government of India.

Rose, D., \& Charlton, K. E. (2002). Quantitative indicators from a food expenditure survey can be used to target the food insecure in South Africa. The Journal of Nutrition, 132 3235-3242.

Swaminathan, M. S. (2001): "Food Security and Sustainable Development", Current Science, Vol. 81, NO. 8, pp. 948-954.

Swindale, A., \& Bilinsky, P., (2007). Months of Adequate Household Food Provisioning (MAHFP) for measurement of household food access: indicator guide, FANTA.

Vanugopal, K. R. (1992): "Deliverance from Hunger: The Public Distribution System in India", Sage Publications, New Delhi, pp. 129-133

World Food Program (2009). Food Security Atlas of Rural Bihar Institute of Human Development and World Food Program, New Delhi. 
